\title{
サガミシンの生合成と発酵
}

\begin{abstract}
抗生物質で代表される二次代謝産物は，その種類の多彩さが生産菌株のわずかな違いによって強調されるの みであった. 放線菌は生化学, 遺伝学の面からは決して使いやすい材料ではなく, 組換えDNA などの新し い育種手法の開発にも, 宿主, ベクターの選択からして難問は山皘している. そして, 何にも增してターゲッ トの選定が頭を悩ませる. 抗生物質生合成経路, 代謝制御機構, 自己耐性機構, 分泌機構などの解明が望ま れる理由がここにある.
\end{abstract}

サガミシン ${ }^{\circledR}(\mathrm{SGM}$ ，一般名：ミクロノマイシ ン) は, 奈良, 川本, 岡地らによって 1975 年に 発見されたアミノグリコシド抗生物質である。生 産菌は相模原市の土塞から分離された新菌種で, Micromonospora sagamiensis と命名されてい る. その化学構造（図 1) からジェンタミシン (GM) グループに属する抗生物質に分類される が, 緑膿菌, セラチア菌, 変形菌属などを含む広 範囲のグラム陽性・陰性菌に強い抗菌力を示すと ともに, アミノグリコシド抗生物質を使用する際 の難点とされている聴器・腎毒 性が, GM や DKB などに比べ 弱いことが認められている。ま た, SGM は $6^{\prime}$ 位のアミノ基が 保護された構造であるため, 近 年日本で増加しているある種の アミカシン $(\mathrm{AMK})$ 耐性菌 $\left(6^{\prime}-\right.$ アミノ基をアセチル化すること によって耐性なセラチア菌, 緑 膿菌）にも有効であるなど，従

* Hirosh1 KASE, 協和酸酵工業株式 会社東京研究所

略号 AMK : amikacin, BTN : butirosin, DKB : dibekacin, DOS : 2-deoxystreptamine, FTM : fortimicin, $\mathrm{GM}$ : gentamicin, $\mathrm{KM}$ : kanamycin, LVM : lividomycin, NM : neomycin, PM : paromomycin, RM : ribotamycin, SDM: seldomycin factor 5, SGM: sagamicin, SM : streptomycin, SSM: sisomicin, TBM : tobramycin, VDM: -verdamicin
来の抗生物質に比べて優れた特徵があり，本年度 から広く細菌感染症の治療薬として臨床に用いら れるようになった。

$\mathrm{SGM}$ は 2-デオキシストレプタミン (DOS, 図 1 のリングII）の C-4，C-6 位に置換体を持ち， 3 つの糖サブニニットからなる抗生物質である. DOS そと構造中に 含むアミノグリコシド抗生 物質としては，GM， KM，TBM， SDM， SSM (SGM 同様 4,6-置換 DOS 抗生物質) p NM, PM, LVM, RM, BTN (4,5-置換 DOS 抗生物

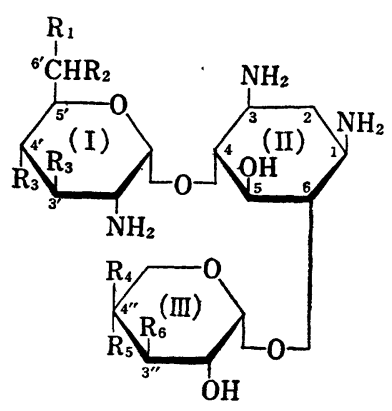

\begin{tabular}{lccccccc}
\hline & & $\mathrm{R}_{1}$ & $\mathrm{R}_{2}$ & $\mathrm{R}_{3}$ & $\mathrm{R}_{4}$ & $\mathrm{R}_{5}$ & $\mathrm{R}_{6}$ \\
\hline パロマミン & & $\mathrm{H}$ & $\mathrm{OH}$ & $\mathrm{OH}$ & - & - & - \\
シェンタミシン & $\mathrm{A}_{2}$ & $\mathrm{H}$ & $\mathrm{OH}$ & $\mathrm{OH}$ & $\mathrm{H}$ & $\mathrm{OH}$ & $\mathrm{OH}$ \\
& $\mathrm{A}$ & $\mathrm{H}$ & $\mathrm{OH}$ & $\mathrm{OH}$ & $\mathrm{H}$ & $\mathrm{OH}$ & $\mathrm{NHCH}_{3}$ \\
& $\mathrm{X}_{2}$ & $\mathrm{H}$ & $\mathrm{OH}$ & $\mathrm{OH}$ & $\mathrm{OH}$ & $\mathrm{CH}_{3}$ & $\mathrm{NHCH}_{3}$ \\
& $\mathrm{G}-418$ & $\mathrm{CH}_{3}$ & $\mathrm{OH}$ & $\mathrm{OH}$ & $\mathrm{OH}$ & $\mathrm{CH}_{3}$ & $\mathrm{NHCH}_{3}$ \\
& $\mathrm{JI}-20 \mathrm{~A}$ & $\mathrm{H}$ & $\mathrm{NH}_{2}$ & $\mathrm{OH}$ & $\mathrm{OH}$ & $\mathrm{CH}_{3}$ & $\mathrm{NHCH}_{3}$ \\
& $\mathrm{JI}-20 \mathrm{~B}$ & $\mathrm{CH}_{3}$ & $\mathrm{NH}_{2}$ & $\mathrm{OH}$ & $\mathrm{OH}$ & $\mathrm{CH}_{3}$ & $\mathrm{NHCH}_{3}$ \\
& $\mathrm{C}_{1 \mathrm{a}}$ & $\mathrm{H}$ & $\mathrm{NH}_{2}$ & $\mathrm{H}$ & $\mathrm{OH}$ & $\mathrm{CH}_{3}$ & $\mathrm{NHCH}_{3}$ \\
& $\mathrm{C}_{2}$ & $\mathrm{CH}_{3}$ & $\mathrm{NH}_{2}$ & $\mathrm{H}$ & $\mathrm{OH}$ & $\mathrm{CH}_{3}$ & $\mathrm{NHCH}_{3}$ \\
& $\mathrm{C}_{1}$ & $\mathrm{CH}_{3}$ & $\mathrm{NHCH}_{3}$ & $\mathrm{H}$ & $\mathrm{OH}$ & $\mathrm{CH}_{3}$ & $\mathrm{NHCH}_{3}$ \\
& & $\mathrm{H}$ & $\mathrm{NHCH}_{3}$ & $\mathrm{H}$ & $\mathrm{OH}$ & $\mathrm{CH}_{3}$ & $\mathrm{NHCH}_{3}$ \\
\hline
\end{tabular}

図 1 サガミシン, ジェンタミシンCおよび関連成分の構造 
質）など多数あるが, SGM, GM はメチル置換基 が多いこと、リング I の C-3'，C-4'に $\mathrm{OH}$ 基がな いこと，さらに DOS の C-6 置換体がガロサミ ンといら珍しい糖である点が特徵的で, この特徵 はその優れた抗菌スペクトルにも反映されてい る. 市販の GM-C には 3 つの成分 $\left(\mathrm{C}_{1 \mathrm{a}}, \mathrm{C}_{2}, \mathrm{C}_{1}\right)$ が含まれているが，それら各成分と SGM は， $6^{\prime}$ 位のメチル置換基の 位置と数によって区別さ れる (図 1).

M.sagamiensis の培養液中には, 主成分 SGM の他に GM-C や多数の GM 類縁化合物がマイナ 一成分として蓄積されている. GM 類縁化合物の ちち, GM-A $,-A,-\mathrm{X}_{2}$, Antibiotic G-418, JI$20 \mathrm{~A}, \mathrm{JI}-20 \mathrm{~B}$ などと呼ばれる抗生物質の構造は 図1に示した。 このように，主生産物の他に数多 くの関連構造のマイナー成分が副生されるのは, 二次代謝の一般的な特徵である.

ところで，抗生物質で代表される二次代謝産物 は，限られた菌株にようて作られ，その化学構造 と生合成は個々の産物や菌株に特異的であり，し がって全体としては複雑多柡である。このため に，一般に有用な二次代謝産物が発見されてその 開発を図る場合は，生合成の知識も遺伝学的知識 もない時点で早く力価を上げ, 評価のための大量 の試料を提供しなければならない，一次代謝産物 であるアミノ酸や核酸関連物質の発酵生産のよ らに, 代謝制御の理論を応用し, 合理的な菌株改 良，培養管理を行なえるところまで，二次代謝の 研究は進んでいないのが現状である.

$\mathrm{SGM}$ の場合も, 当初は生合成や代謝制御の知 識がほとんどない状態から研究をスタートした が，ランダムスクリーニングを中心とする菌株の 改良を進める一方で, 生合成や代謝制御の研究も 進め, これを合理的な菌株改良や培養管理へ応用 することを試みてきた。また，生合成の研究と相 補いながら，M. sagamiensis の持つ多様な代謝系 一活用七て，より改良されたアミノグリコシド抗 生物質を探索する方向にも研究を進めていった. ここでは, それらの研究をまとめ, 抗生物質研究 の進め方の一例という意味で, 他の抗生物質 (特 にアミノグリコシド系）とも比較対照しながら，
紹介してみたい。

\section{SGM の生合成経路}

アミノグリコシド抗生物質の生合成経路で酵素 レベルまで詳細に研究されたのは SM だけであ り, 他は NM, RM, BTN, KM, GM につい て，主に 1）ラベル化合物のとり込み実験，2） idiotroph（二次代謝のブロックされた変異株. 生 育は prototrophic であるが，二次代謝産物の生 産に特定の生合成前駆物質を必要とする。一次代 謝の auxotroph に対応する) を用いた微生物転換 反応，の 2 つの手法により，仮の生合成経路が提 唱されている(1).

SGM の生合成経路については, Testa と Tilley $^{(2)}$ が GM 生産菌である M.purpurea より 変異誘導したパロマミン生産性変異株（図 3 の経 路でEがブロックされていると推定される株)を 使って; GM マイナー成分からの転換実験の結果 を基にした推定経路を提案している．この経路は パロマミンから始まり， GM-A， $\mathrm{X}_{2}$ の共通中間 体を経て, 一方は C-6' にメチル分枝を持った $\mathrm{G}-$ $418 \rightarrow \mathrm{JI}-20 \mathrm{~B} \rightarrow \mathrm{GM}-\mathrm{C}_{2} \rightarrow \mathrm{GM}-\mathrm{C}_{1}$ に至る 経路, 他方は C-6' にメチル分枝を持たない JI-20 A $\rightarrow \mathrm{GM}-\mathrm{C}_{1 \mathrm{a}} \rightarrow \mathrm{SGM} \quad\left(=\mathrm{GM}-\mathrm{C}_{2 \mathrm{~b}} ; \mathrm{SGM}\right.$ 発見後 M. purpurea の変異株で $\mathrm{GM}-\mathrm{C}_{2 \mathrm{~b}}$ として見いだ されている）の経路，の2つに分枝するというも のである (図 3 参照).この研究は, 微生物䎐換に よる生成物の同定をペーパークロマトグラフィー (PPC) のみで行なっている点で限界があり, 正 確を期するためには転換生成物を単離同定する必 要があるし，また他の中間体が関与している可 能性も大いにあった，そこで筆者らは，1） $M . s a-$ gamiensis より生合成がブロックされた変異株 (blocked mutant) を多数誘導分離し, その生産 物を単離同定する，2）変異株および親株の培養 液から単離された物質を blocked mutant の静止 菌体を用いた転換反応系に加えて 転換生成物を 同定する，3) blocked mutant どうしを組み合わ せた SGM の co-synthesis（後述）などを検討 して SGM 生合成経路をさらに解明しょうと試み た: 
表 1 M. sagamiensis 变異株の生産物と生合成ブロック位置

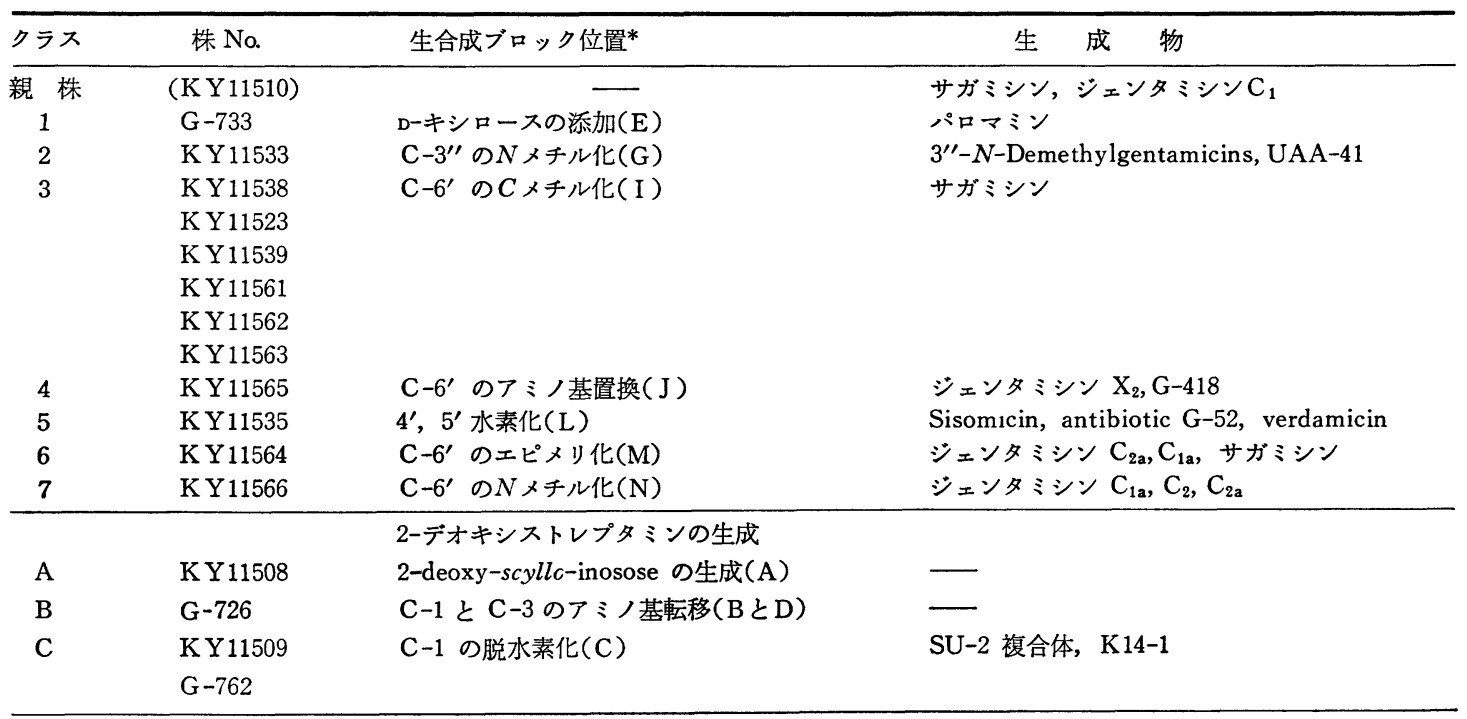

* 生合成ブロック位置のうち, $\mathrm{A} \sim \mathrm{C}$ は図 7 に, E〜Nは図 3 に示した.

M. sagamiensis をニトロソグアニジンなどの変 異剤で処理し, 親株が生産する SGM や GM-C を生産しえなくなった変異株を選ぶと，その中に blocked mutant が得られる. 得られた株を, 可溶 性でんぷん, soy bean meal などを含む栄養培地 で培養し，培養液中に蓄積してくるアミノグリュ シドをイオン交換樹脂やシリカゲルなどのカラム クロマトグラフィーを使って精製単離し, マスス ペクトルや NMR で同定した. 次にこれらの化 合物を変異株の洗浄菌体とともに緩衝液中で振燙 し，生成物をペーパークロマトグラフィーや薄層 クロマトグラフィー (TLC) で同定する.クロマ トグラフィーだけでは同定が難しいものは，反応 液から生成物を精製単離した後同定した，表 1 に は, 分離された blocked mutantsの生産物と, 生合成の欠損部位ををとめた. 10 の異なった 欠損部位（そのうち 3 株は DOS 生合成が欠損） を持った変異株が得られ，それらを用いて，上 に述べたような検討を一つ一つ行なった結果,

SGM 生合成経路は図 3 のように決められた。こ の経路は先の Testa と Tilley の推定経路を大筋 に打いて支持しているが，新規に見つかった化合 物も含めて，いくつかの新しい中間体（SSM, VDM， GM-C 2 a UAA-41，TPJ-B）を加えるな ど，新たな知見を含めた結果をまとめたものであ
る. 以下, それらの研究過程を中心に, SGM 生 合成について述べてみたい，な拉，DOS 生合成 については 3 章で述べる.

\section{1） SGM 生合成中間体としての SSM 系抗生 物算}

SSM 系抗生物質は, 図 2 に示すよらに SGM, GM の C-4' と C-5' の間に二重結合が入った構 造をしており，抗菌スペクトルも GM に類似 する. SSM, VDM および G-52 が知られてお りそれらは 6' 位の構造に関してそれぞれ GM-

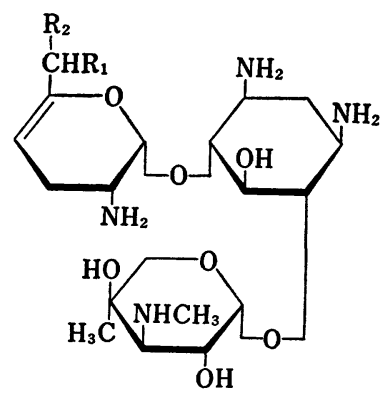

\begin{tabular}{lcc}
\hline & $\mathrm{R}_{1}$ & $\mathrm{R}_{2}$ \\
\hline Sisomicin & $\mathrm{NH}_{2}$ & $\mathrm{H}$ \\
Verdamicin & $\mathrm{NH}_{2}$ & $\mathrm{CH}_{3}$ \\
G-52 & $\mathrm{NHCH}_{3}$ & $\mathrm{H}$ \\
$6^{\prime}-\mathrm{NMV}$ & $\mathrm{NHCH}_{3}$ & $\mathrm{CH}_{3}$ \\
\hline
\end{tabular}

図 2 シソミシン系抗生物算の構造 


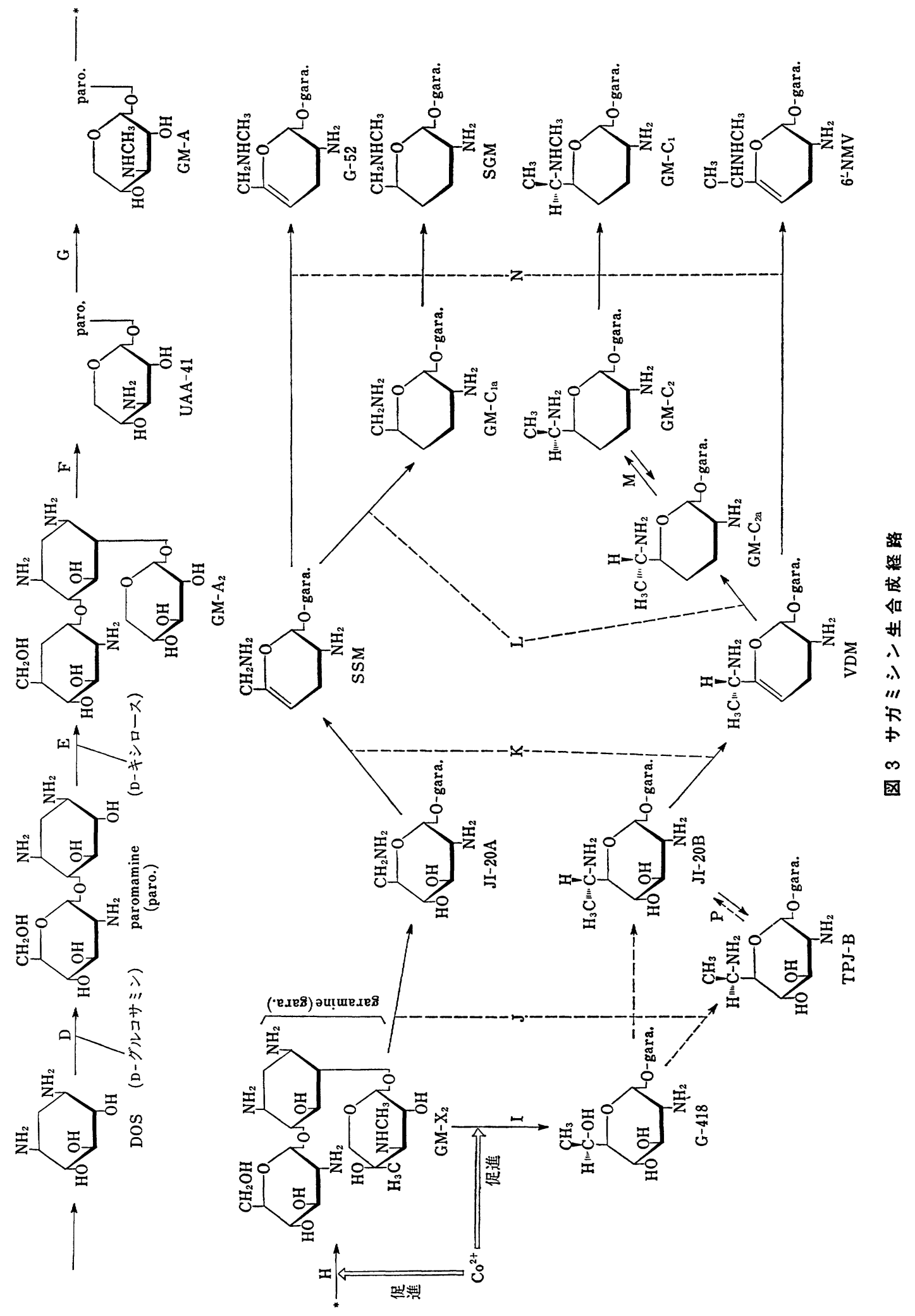


$\mathrm{C}_{1 a},-\mathrm{C}_{2}$ および $\mathrm{SGM}$ に対応する. 生産菌はい ずれも Micromonospora 属に属し, M. inyoensis (SSM 生産), M. grisea (VDM 生産), M.zionensis (G-52 生産) が報告されている. GM 生産 菌や M.sagamiensis では, 通常これらの抗生物 質の蓄積は検出されない。筆者らは，M.sagamiensis の DOS idiotroph* KY 11525 を使い, 各種 化合物からの転換反応を検討した際に，SSM 系 抗生物質からの転換反応についても調べてみた。 これは，一つには，未発見の 6'-NMV（図2参 照）の生成を期待して行なったものであるが，結 果は予想に反していた. SSM は GM-C $\mathrm{SGM}$ へ, VDM は $\mathrm{GM}-\mathrm{C}_{2 \mathrm{a}}\left(\mathrm{GM}-\mathrm{C}_{2}\right.$ の C-6' の エピマー) $\rightarrow \mathrm{GM}-\mathrm{C}_{2}$ を経て $\mathrm{GM}-\mathrm{C}_{1}$ へ転換された のである(図 3 のステップ L, M, N 参照). この 転換系の分析は，似たような化合物を分離しなけ ればならないので，従来普通に用いられた PPC や TLC による方法ではかなり困難である. 実際 に, SSM が M. rhodorangea により $\mathrm{SGM}$ へ 転換されたといら報告 ${ }^{(3)}$ はあるが，中間体 (GM$\mathrm{C}_{1 \mathrm{a}}$ ）の分離同定には失敗している. 筆者らは, $\mathrm{SSM}$ 系と GM 系の抗生物質の分離が良いカーボ ン $\mathrm{TLC}^{(4)}$ を使うと,さらに $\mathrm{GM}-\mathrm{C}_{2 \mathrm{a}}$ と $\mathrm{C}_{2}$ も分 離できることを見つけ，上の経路を決めることが できた，反応生成物は反応液より単離し同定した が，G-52や 6'-NMV の生成はどちらの転換系で も認められなかった. 一方, M. inyoensis や $M$. zionensis では，この二重結合を還元する活性 $\left(4^{\prime}, 5^{\prime}\right.$-水素化) が検出されなかった. その代り に, G-52 生産菌の M. zionensis では SSM が G-52 へ転換した.

転換反応の 結果から, M. sagamiensis でも， $4^{\prime}, 5^{\prime}$-水素化（図 3 の L) 活性が欠失した变異株 を誘導すれば SSM 系抗生物質が蓄積可能ではな いかと考え, SGM 生産菌 KY 11523 を変異処理 後, 液体培養して SSM 系抗生物質に着目した スクリーニングを行なった. その結果， G-52 を 蓄積する KY 11535 を選択できた. KY 11535 は

*抗生物質の生産に DOS を要求する変異株. アミノグリコ シド抗生物質の生合成研究や Mutational biosynthesis に 広く用いられている.
副産物として SSM，VDM を生産したが，SGM や GM-C 群は蓄積しない。転換実験から，KY 11535 は 4', 5'-水素化活性が 欠損していることが 確認された．本菌は，SSM から G-52 が，VDM から未知抗菌物質 $\left(6^{\prime}-\mathrm{NMV}\right.$ と同定されるが，こ のことは後述する)を生成するまた，DOSをは じめ各種 SGM 生合成前駆体から SSM 系抗生物 質を生成した。これらの結果から，SSM，VDM は, 一図 3 に示すように SGM，GM 生合成の中間 体であることが示された．親株では水素化の活性 が強いため, SSM 系抗生物質が 蓄積しにくく， この活性の欠損で SSM, VDM と，その直接の $6^{\prime}-N-メ チ ル$ 化化合物 G-52 が蓄積されたと考え られる。

KY 11535 は，スクリーニングではよほど注意 しないと，親株との区別が難しく見落しやすい変 異株であるが，転換反応の結果からの想定が加わ った結果，比較的たやすく選択されてきたといえ る.また，初めにも述べたように，抗生物質生産 は，一般に菌株特異的であるといわれ，SSM， VDM，G-52 も各々別個の菌株で発見され，GM 系抗生物質とは生産菌も生合成系も別であるよう に考えられたが，実際は1つの酵素によって，何 が生産されるかが支配されていたと考えられる点 で興味深い.

\section{2) $\mathbf{G M}-\mathbf{C}_{2 a}$}

$\mathrm{GM}-\mathrm{C}_{2 \mathrm{a}}$ は, その構造から $\mathrm{GM}-\mathrm{C}_{2}$ 生合成の中 間体であることが推定されていたが，他の成分 (特に $\mathrm{GM}-\mathrm{C}_{2}$ ) との 区別が 難しいために 実験的 には示されていなかった. 先の実験で, VDM $\rightarrow$ $\mathrm{GM}-\mathrm{C}_{2 \mathrm{a}} \rightarrow \mathrm{GM}-\mathrm{C}_{2} \rightarrow \mathrm{GM}-\mathrm{C}_{1}$ の 転換経 路を証明 したが，このことは， GM-C $\mathrm{C}_{2 a}$ が $\mathrm{GM}-\mathrm{C}_{1}$ 生合成 の中間体であることを示している.ささらに，6'$\mathrm{C}$ のエピメリ化（図 3, M) が欠損 L $\mathrm{GM}-\mathrm{C}_{2 \mathrm{a}}$ を生産する変異株 KY 11566 が得られ，この株 を使った転換実験でも確認された， GM-C 2 a から $\mathrm{C}_{2}$ への異性化反応は可逆的であった.

\section{3) TPJ-B}

KY 11525 (DOS $\left.^{-}\right)$による G-418 または JI- 
$20 \mathrm{~B}$ の転換実験の際, 主生成物である $\mathrm{GM}-\mathrm{C}_{2}$, $-\mathrm{C}_{2 \mathrm{a}},-\mathrm{C}_{1}$ の他に, JI-20 B の 6'-エピマーと同定 された TPJ-B が生成してくることを見つけた. この転換は, 反応初期に TPJ-B が生成し, 次い で消失にともなって $\mathrm{GM}-\mathrm{C}_{2},-\mathrm{C}_{1}$ がこの順に生成 するという経時変化を示した. TPJ-B は, GM$\mathrm{C}_{1}$ 生合成経路上, G-418 から JI-20 B へ転换す る際の中間体である可能性があるが, 別の可能性 として, 生合成経路からの分枝生成物であること も考えられよう、G-418 から GM-C 2 へ至る経 路の C-6' 位に関する立体化学をも含めた転換に ついては，まだ検討が十分とはいえないので，今 後それらについて詳細な解明が待たれる.

\section{4）分枝後の経路の共通反応}

$\mathrm{GM}-\mathrm{X}_{2}$ より分枝後, 各々 $\mathrm{GM}-\mathrm{C}_{1}$ および $\mathrm{SGM}$ へ至る経路は，ステップ J, K, L, N にお いて共通した反応で進行する（図 3）. 各ステッ プの欠損変異株は，いずれも両経路の転換能が同 時に欠け, $\mathrm{SGM}$ と $\mathrm{GM}-\mathrm{C}_{1}$ の両方の生産能がな くなるとともに，両経路の 欠損部位の直前の中 間体 ( $\mathrm{J}$ の欠損株では G-418 と GM-X $\mathrm{X}_{2}, \mathrm{~L}$ は $\mathrm{SSM}$ と VDM, N は $\mathrm{GM}-\mathrm{C}_{1 \mathrm{a}}$ と- $\left.\mathrm{C}_{2 \mathrm{a}},-\mathrm{C}_{2}\right)$ を 著量生産していた（Kの欠損株は得ていない). このことは，各ステップには， 6'-C-メチル基に 特異性を持たない酵素が関与していることを示唆 している.

\section{5) UAA-41}

$\mathrm{SGM}$ 生産菌 $\mathrm{KY} 11523$ より変異誘導した SGM 非生産株, KY 11533 は, 一連の $3^{\prime \prime}-N-テ ゙$ メチル化合物（図 1 の $\mathrm{R}_{6}$ の $N$-メチル基がない 化合物）を生産した. 単離同定した 10 物質のう ち，新規物質としては，UAA-23, -26,-30,-41, -49（それぞれ JI-20 A, SSM， G-52， GM-A， garamine の $3^{\prime \prime}-N$-デメチル誘導体), UAA-22,

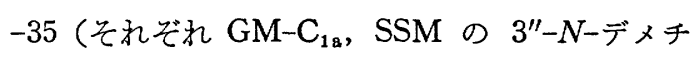
ルー3"-N-アセチル誘導体) が見いだされた. その 他, 天然からは初めて見つかった UAA-25（3"$\left.N-テ ゙ メ チ ル-G M-C_{1 a}\right)$, 既知物質 UAA-38, $\left(\mathrm{GM}-\mathrm{A}_{2}\right), \mathrm{UAA}-24\left(3^{\prime \prime}-N-\right.$ デメチル SGM) が

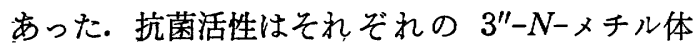
と比べ，1/2 かそれ以下であった. KY 11533 と， その単離された生産物とを使った転換反応の結果 から，1） UAA-41 (3"-N-デメチル GM-A) が $\mathrm{GM}, \mathrm{SGM}$ 生合成の中間体であること（図 3), 2) KY 11533 は, UAA-41 から GM-A の転換活 性（3"-N-メチル化，ステップG）を欠損してい

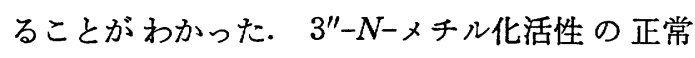
な DOS idiotroph KY 11525 は, 生合成経路上 $\mathrm{JI}-20 \mathrm{~A}$ 以後の中間体の $3^{\prime \prime}-N-$ デメチル誘導体を 容易に $3^{\prime \prime}-N$-デメチル SGM へ転換する. 一方, KY 11533 はステップ G以外の生合成は正常であ った. したがって，KY 11533 はステップGの欠 損により蓄積した UAA-41 が，直接次のステッ プ（H）を経て SGM 生合成系にとり込まれ， 一連の $3^{\prime \prime}-N$-デメチル体を生成したと考えられ る.

以上，筆者らの得た新しい知見を中心に SGM 生合成をやや詳しく紹介したが，ここで他のアミ ノグリコシド抗生物質の生合成と比較し， SGM 生合成の特徵と問題点について若干考察を加えて 扣きたい。

$\mathrm{SGM}$ 生合成の各構成糖の結合順序は, DOS+ $\mathrm{D}$ グルコサミン=パロマミンが先で, 次に D-キ シロース相当の糖が結合することを示した. この 順序が逆である可能性は低いと考えられる．他の アミノグリコシドでも，糖の結合順序を確定する のは難しい問題であったが，最近，各抗生物質 で明らかになりつつある. それによると， RM， BTN, NM, PM の場合も，まずパロマミン相当 の二糖類が生成するようである，この最初の系 は，菌株により多少の違いはあるかもしれない が，放線菌，細菌を含めて DOS 含有抗生物質 に，かなり共通したものと推測される。一方， $\mathrm{SGM}$ 生合成で D-キシロースが直接パロマミンに 結合する糖であるか否かについては明らかでな い. 他の糖が 結合後 Dーキシロースへ変換する可 能性もあろう.

DOS を含む抗生物質では，いずれも DOS が そのまま抗生物質にとり込まれるが，他の構成ア 
ミノ糖のとり込まれ方は; 各抗生物質で異なって いる. SGM では Dーグルコサミン, DOS, D-キシ ロースで構成される $\mathrm{GM}-\mathrm{A}_{2}$ が完成後, 各アミノ 糖のメチル化，アミノ化，異性化などの修飾が進 行する経路が示された. Grisbach ${ }^{(5)}$ は, SGM の L-garosamine（図1のリングIII）部分の生合成と して，ペントースー4-ウロースヌクレオチドのメ チル化で Nuc DP-L-garosamine 生成後, これが 他の糖と結合すると考学るほうが妥当であると提 案している．その可能性を完全に否定はできない が，変異株を使ったこれまでの結果からは，図3 の経路のほうがより妥当と考える． SM の場合 は，燐酸またはヌクレオチドと結合した形で各 構成糖の変換が進み，その後に互いが結合して $\mathrm{SM}$ が完成する.一方, SGM と同じような例は, BTN (アミノ化, 1-N-amino-2-hydroxybutylation, イソメリ化), NM, PM(アミノ化,イソメ リ化）などでもみられる。しかしながら，これら の場合も，各構成糖間の結合の際には， ヌクレオ チドや燐酸と結合した形を考学た注うがよいであ ろう。その後の反応にも，遊離型でなく，燐酸 化，アセチル化，ヌクレオチド化された誘導体が 実際の生合成に関与している可能性が 考元られ る.これは, 自己耐性機構にもかかわる問題で, $\mathrm{SM}$ や $\mathrm{NM}, \mathrm{KM}$ の生合成では, 燐酸化やアセチ ル化の関与が報告されている．また，いくつかの 生産菌で, 自己抗生物質の不活化酵素が見つかっ ている. しかし，M.sagamiensis では，不活化物 や不活化酵素はまだ見つかっていない.

$\mathrm{SGM}$ 生合成経路は, 一応, 図3 3 ように描く ことができたが，上に述べた問題点を含めてまだ 確定されない部分や不明な点も多く，今後さらに 多くの変異株の分離や，遺伝も含めた解析，酵素 レベルでの検討が必要とされよう.

\section{SGM 生合成の調節機構と生産菌の改良}

抗生物質を含む二次代謝産物は, 生育に関与し ない物質群に対してあてられた言葉であり，普通 は生育の急速な時期 (trophophase) には作られ ず，続いての生産期 (idiophase) に作られる.し たがって, 二次代謝の調節機構は大きく分けて,
生合成の開始がどのような因子でいかに制御され ているかと; 開始後の生合成の調節がぞのように 行なわれるか，の 2 つになるかと思われる．前者 は，栄養条件や生育速度に関わるもので，ある条 件で特定の栄養素の欠乏から生育がアンバランス になりこれが何らかの引き金となって二次代謝 酵素の 脱調節（生合成の 抑制，阻害の 解除や誘 導, 活性化) につながり，二次代謝が開始される と考えられる. carbon catabolite regulation, 窒 素代謝（アンモニア）による制御，燐酸塩による 制御や，特定の誘導物質による制御などがこれに 関連した機構として挙げられる。一方，後者とし ては，二次代謝産物自身による feed back 制御 (抑制, 阻害) や，生合成酵素の不可逆的分解など が挙げられよう。また，二次代謝は，鍵前駆物質 を介して一次代謝と生合成的にも調節的にもつな がっている*. SGM 生合成の 調節機構について も, 上記の観点から種々の検討がなされたが，こ こでは自己抗生物質耐性あるいは生合成制御と, 金属イオン $\left(\mathrm{Co}^{2+}\right)$ による $\mathrm{SGM}$ 生合成の調節に ついて触れてみたい.

SGM の生産は, 培養の生産期（培養開始後 7 〜 9 日目）に生産培地に GM-C $2 \sim 3 \mathrm{mg} / \mathrm{ml}$ を添 加すると阻害される。 このとき菌の生育は阻害 されない，一方，培養開始時に GM-C を添加し た場合には，約 $100 \mu \mathrm{g} / \mathrm{ml}$ の濃度で菌の生育, $\mathrm{SGM}$ 生産ともに完全に阻害されてしまう。この 結果は, 培養が進み $\mathrm{SGM}$ が生産されるのと併行 して，GM-C に対する酎性を生産菌が獲得する 機構が働いていることを示唆するとともに，生産 期での結果は SGM 生合成が GM-C によって阻 害を受けていることを予想させる．培養各 phase での ${ }^{3} \mathrm{H}-\mathrm{GM}$ の細胞内とり込みをみたところ, 培養 2 日に比べて 7 日目のとり込みは $1 / 4 \sim 1 / 5$ に減少していたことから，生育にともなう耐性の 獲得の一つの機構として, GM 透過性の減少が考

\footnotetext{
*アミノグリコシド抗生物質では細胞壁合成（一次代謝）と の関連が論ぜられている. SGM の生成に执いても, 細胞 壁合成阻害剤（バシトラシンなど）の添加が SGM 生産を 增加させ, グルコサミンの細胞壁へのとり込みを抑制し， SGM へのとり込みを增加させたといら結果が得られてい る.
} 
えられた. 耐性獲得の同様の現象は他の抗生物質 でる一般的潅察されており，また抗生物質生成 量は生産菌の自己抗生物質に上る生産阻害濃度々 ほぼ一致することもよくみられるので，逆住産 菌の生産能を上げるための育種法として，自己耐 性株を選択することが一つの有効な方法とされて いる. SGM 生産菌の場合は, SGM 低生産菌から 変異誘導した GM 耐性株の中には, SGM 生産が 增大した株が得られたが，SGM 高生産株から誘 導した GM 耐性株は SGM 生産が著しく低下 乙, GM 耐性と SGM 生産性はむし万逆相関の関 係になり，自己耐性に上る菌株改良は必ずしもう まくいかなかった。しかし，この低生産変異株の 中には, GM-C $(200 \mu \mathrm{g} / \mathrm{ml})$ を培盖開始時に添加 すると, SGM 生産が著しく(6〜15 倍) 促進され る (autostimulation) 株が得られた. その詳しい 機構は不明であるが，似たような現象は，エリス ロマイシン発酵でェリスロマイシン自身による生 産の促進が報告されている．この他にも，蛋白質 合成阻害剂による抗生物質生産性促進の例はいく つかあり，それらの現象を実際の抗生物質生産収 量の増加沁応用することも面白いかと思われる.

さて, SGM は，その分子中に 3 個のメチル置 換基を持っ（図 1）が，これらのメチル基は L[メチル-14 $\left.{ }^{14} \mathrm{C}\right]$ メチオニンの SGM へのとり达み

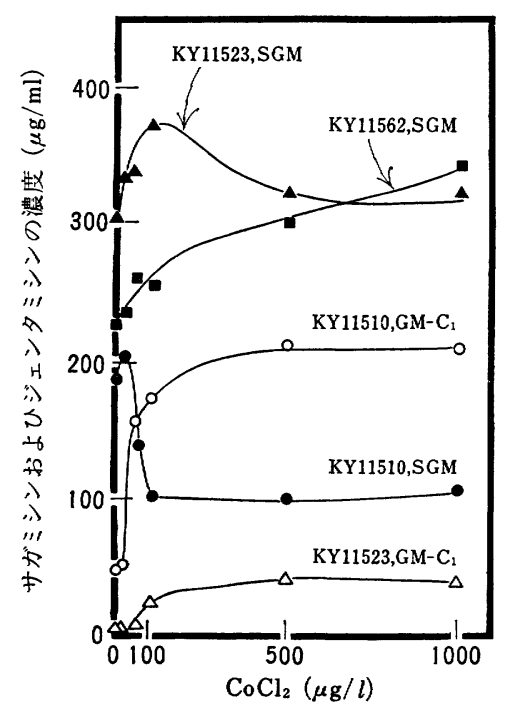

図 4 塩化コバルトのサガミシンおよびジェンタミ シン $\mathrm{C}_{1}$ 生産に及ばす影響
実験の結果から，いずれもメチオニンに由来し ていることが証明されだ(11).このメチオニンによ るC-および $N$-メチル化のうち，C-メチル化反 応のコバルトイオンによる調節と, その調節を利 用した菌株改良について次に述べてみたい。

前述のよう飞, M. sagamiensis 注, 主生産物 SGM の他に, 多くの成分を副生するが, 中でる $\mathrm{GM}-\mathrm{C}_{1}$ の副生量は多い, 特に, 培地飞塩化コハ ルトを添加すると， GM-C 1 生産は著しく増大す る一方, $\mathrm{SGM}$ 生産量は, $\mathrm{Co}^{2+}$ 低濃度で若干促進 されるものの，それ以上では著しく抑制され， GM-C 1 が主生産物飞代ってしまう（図４の KY 11510).この $\mathrm{GM}-\mathrm{C}_{1}$ の副生を抑兄る目的で, $\mathrm{KY} 11510$ より $\mathrm{GM}-\mathrm{C}_{1}$ 非生産株の変異誘導を 試みた。塩化コバルト $1 \mathrm{mg} / l$ でも $\mathrm{GM}-\mathrm{C}_{1}$ を生 産しない株を選しだところ, 表1飞示したクラス 3,4,6,7 の菌株が選ばれてきたが，このらちクラ ス 3 の 6 株の及が SGM を著量生産し, GM-C は生産しなくなっていた，転換反応の解析の 結 果, クラス 3 の変異株は $6^{\prime}-C$-メチル化（図 3 の ステップI）が欠損していることがわかった. 図 4 亿代表 2 株, KY 11523 とY 11562 の培養の 結果を示す、興味あることに，これらの変異株は $\mathrm{Co}^{2+}$ により $\mathrm{SGM}$ 生産が促進された. KY 11562 は, $\mathrm{Co}^{2+}$ 無添加で培盖した時の SGM 生産が親 株より若干上まわったが，塩化コバルトの添加に より濃度に依存して, SGM 生産はさらに増大し た. 一方, KY 11523 は少量の $\mathrm{GM}-\mathrm{C}_{1}$ を副生す る leaky 型の変異株であるが, $\mathrm{Co}^{2+}$ 無添加時の $\mathrm{SGM}$ 生産は親株の約 1.5 倍になり, 塩化コバル 卜 $100 \mu \mathrm{g} / \mathrm{ml}$ までは添加量に依存して SGM 生産 量が増大した. $\mathrm{Co}^{2+}$ に依存するステップとして C-6' (ステップI) および C-4" (ステップH)のメ チル化が M. purpurea で報告されている(2)（図 3). 一方, $N$-メチル化は $\mathrm{Co}^{2+}$ の影響を受けな い. M. sagamiensis でも, 転換反応系に $\mathrm{Co}^{2+}$ を 添加する実験で同様の結果が得られた. KY 11510 では 2 つの $C$-メチル化反応が $\mathrm{Co}^{2+}$ で促進 されて, GM-C 1 生産が增大すると考穴られる. $\mathrm{SGM}$ 生産の $\mathrm{Co}^{2+}$ による阻害の原因が， $\mathrm{SGM}$ 生合成のどこかのステップの $\mathrm{Co}^{2+}$ による阻害で 
ないことは, クラス 3 の変異株の SGM 生産が $\mathrm{Co}^{2+}$ で阻害されないことからも推測できる. $\mathrm{Co}^{2+}$ による SGM 生産阻害の原因としては, $6^{\prime}-C$-メ チル化の $\mathrm{Co}^{2+}$ による促進によって, 共通の前駆 体 $\mathrm{GM}-\mathrm{X}_{2}$ が $\mathrm{GM}-\mathrm{C}_{1}$ 合成のほうへより多く流れ た結果 SGM 生産が減少したと考えるのが妥当で あろら.6'-C-メチル化の欠損した株では, GM-C 合成への分枝がなくなるので，その分 SGM 生産 は増大し，また $\mathrm{Co}^{2+}$ を添加すると $4^{\prime \prime}-C$-メチル 化が促進されるため， SGM 生産がさらに上昇し たと考えられる。この変異株では $\mathrm{GM}-\mathrm{C}_{1},-\mathrm{C}_{2}$ を生産しないので，先に述べた GM-C による $\mathrm{SGM}$ 生産阻害が軽減されていることも考えられ, これが SGM 生産性増強に関与している可能性 もあろう。

このように，生合成の分枝点の blocked mutant を用いることで, 副生物 $\mathrm{GM}-\mathrm{C}_{1}$ の生成が抑 えられたばかりでなく， $\mathrm{Co}^{2+}$ などによる代謝制 御が，SGM 生合成のほうへ都合よく働くように なり, SGM 生産が著しく改良された.

\section{3. 新規アミノグリコシト抗生物質の検索}

各種の細菌感染症の治療に新抗生物質が導入さ れると、しばらくしてその耐性菌が出現し，治療 上の障害となる．アミノグリコシド抗生物質の場 合，耳や腎臓に対する毒性も問題とされている. この耐性菌と毒性の問題を克服する新薬を開発す るために様々な努力が払われている．従来の土壌 スクリーニングや既存物質の化学修飾に加兄, 抗 生物質生産菌の微量成分を探索したり, idiotroph にその要求成分のアナログを与える mutational biosynthesis といった方法が使われている.

筆者らは，M. sagamiensis の代謝活性を利用し て新規抗生物質を探すといら考えで，1）変異株 の生産物の探索，2）転換反応および mutational biosynthesis，3）変異株相互の混合培養，などに ついて検討し，いくつか 興味ある 新規物質を得 た.

\section{1） SU-2 関連物質之 DOS 生合成}

生合成の研究で DOS idiotroph をよく使って

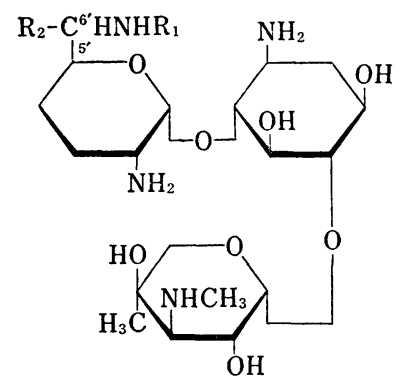

\begin{tabular}{ccc}
\hline & $\mathrm{R}_{1}$ & $\mathrm{R}_{2}$ \\
\hline $\mathrm{SU}-1$ & $\mathrm{H}$ & $\mathrm{CH}_{3}$ \\
$\mathrm{SU}-2$ & $\mathrm{H}$ & $\mathrm{H}$ \\
$\mathrm{SU}-3$ & $\mathrm{CH}_{3}$ & $\mathrm{H}$ \\
\hline
\end{tabular}

\section{図 5 SU-2 および関連抗生物質の構造}

きたが，この変異株は，DOS を添加しない培地 で培養した時は抗生物質を作らないものとされて いた.ところが, M. sagamiensisから何株か得ら れた DOS idiotroph の中に微量の抗菌活性物質 を蓄積する株があることを，この変異株を使って の転換反応生成物の分析中に偶然に見いだした。 DOS idiotroph KY 11509 の培養液上清を弱酸性 陽イオン交換樹脂 Amberlite IRC-50 で処理後, 約 1,000 倍に濃縮し, 生産物をTLC で分析する と，4〜5 個の未知抗菌物質が認められた. 主成 分を SU-2 と命名し, 大量培養液から精製を試み $\tau$, SU-2 の他に SU-1, -3,-4，(SU-3,-4 は以前 は SUM-3，SUM-4 と報告）を単離した. SU一 $2,-1,-3$ はいずれも新規* で，それぞれ GM$\mathrm{C}_{1 \mathrm{a}},-\mathrm{C}_{2}, \mathrm{SGM} の$ 1-deamino-1-hydroxy 誘導体 というユニークな構造と同定された（図 5). SU一 4 の推定構造は， 3'-hydroxy SU-2 が考学られ ている.

SU-1, -2,-3 は, いずれも抗菌力は SGM, $\mathrm{GM}$ より若干劣るものの,な招相当の抗菌力を保 持しており，ある種の GM，SGM 耐性菌に対し ても有効であった. DOS の1位のアミノ基の修 飾は，天然から発見されたBTN [RM の 1-N(4-amino-2-hydroxybutyryl 誘導体], KM-A の 化学修飾による同誘導体 AMK や, SSM の 1$N$-エチル誘導体 netilmicin など，耐性菌に対す る活性や毒性の 改良の面で実際的な成果が得ら れ，今後も注目されると考えられるが，その意味 で SU-2 各成分の 強い抗菌力とスペクトラムは

* SU-2 各成分発見後間もなく, Mallams により GM, SSM の 1-deamino-1-hydroxy 誘導体合成の発表があった. 
示唆に富んでいる.

さて，筆者らは，SU-2 成分 のアミノサイクリトールが 2deoxy-scyllo-inosamine (DOI) であることに特に興味を持っ た. DOI は天然からは発見さ れていなかったし，SU-2 成分 がぞんな機構で生成したかとい ら疑問があった。

まず, DOS 要求性と SU-2 生産の関係をみるため, $M . s a$ gamiensisの他のDO Sidiotroph 3 株について SU-2 生産性を調 ベたところ，G-762 は SU-2 を 生産し, KY 11508, G-726 は生

産しないことがわかった(表 1). DOI は, Rinehart ら (1)によって DOS 生合成の一つの可能な中間体 として想定されており, SU-2 生産性の菌株によ る違いは, DOS 生合成上のブロック位置の違い によるのではないかと考え, その点を検討するこ そにした、ところが，DOS は SM を除く実用上 重要なアミノグリコシド抗生物質の大半に含まれ ているにもかかわらず，当時その生合成について は不明な部分が多かった. Rinehart ら(1)は，NM 生産菌 Streptomyces fradiae を用い, ラベルした グルコースやグルコサミンの DOS へのとり込み 実験の結果に基づいて，グルコースからサイクリ トールに転換後図 6 の (1)，(2)，(3)（またはその 対掌体)を経て DOS が生成する経路を推定し た.この経路のどの段階でデオキシ化が起こるか は不明であったが, Daum ら DOS idiotroph を用いた各種サイクリトールから の mutational biosynthesis の結果から, 上の推 定経路がほぼ正しいこと, また（1）のラセミ体 やある種の deoxycyclitol がGM へ転換されるの で, デオキシ化は生合成のかなり初期で起こると 推定した.

これらの知見を参考にし，M.sagamiensis の各 DOS idiotrophを使って, co-synthesis（異なっ た blocked mutant ぞうしの組み合わせで抗生物 質の生成の有無をみて, ブロックの相対位置を知

ることができる)，各種サイクリトールの転換実 験, および idiotroph の蓄積中間体の同定を検討 した.こうして, 1) KY 11509 と G-762 は, ア ミノサイクリトール，K 14-1 を大量蓄積する. K 14-1 は精製単離後 DOI（図6の（2）または その対掌体) と同定された；2）K 14-1 と2deoxyinosose [(1) のラセミ体]は, KY 11509, G-762 によっては SGM へ転換されないが，別の DOS idiotroph KY 11508 により SGM へ転換 される、またinosose, inosamine, ストレプタミ ンは KY 11508 により新規物質 2-hydroxy SGM へ転換された (mutatinal biosynthesis);などの 結果から, DOS 生合成経路と各 idiotroph の欠損 部位を図6のように考えた（ただし3は推定化合 物). KY 11509 と-762 は DOI の直後のステ ップ Cが, KY 11508 はグルコースから (1) へ至 る経路のどこかでブロックされていると考えられ る. G-762 は, co-synthesis と転換実験で KY 11509 と区別されないが，K 14-1 や SU-2 は生 産しない.ステップ BとDはアミノ基の転移反応 で,この aminotransferase を無細胞抽出物を用い て検討した Walker ら (7)が推定しているように， 両ステップを同一酵素が触媒していると考え, G-726 がこの aminotransferase 欠損株と考える と結果がうまく説明される. 以上は，M. sagami-

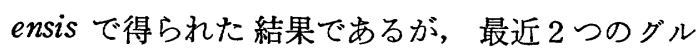




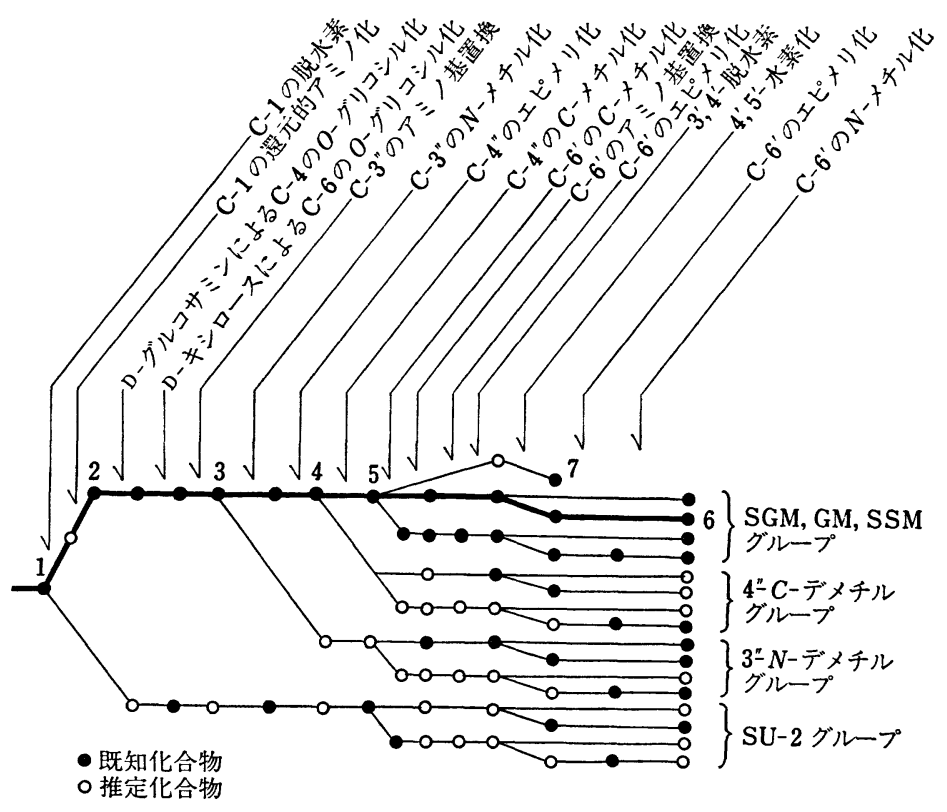

図 7 M. sagamiensis のサガミシンおよび関連アミノグリコシド生合 成系

1. 2-deoxy-scyllo-inosamine, 2. デオキシストレプタミン, 3. UAA-41, 4. シ エンタミシン $\mathrm{A}_{1}$, 5. ジェンタミシン $\mathrm{X}_{2}, 6$. サガミシン, 7. 6'-deamino-6'hydroxygentamicin $\mathrm{C}_{1 \mathrm{a}}(\mathrm{UAA}-3)$

一プ(8,9)で報告されている, BTN 生産菌 Bacillus circulans の DOS idiotrophを用いた DOS 生合 成の研究結果も，これらと矛盾する点はない。特 に, 藤原ら ${ }^{(9)}$ は, DOS idiotroph より DOI を単 離し，絶対構造も含めて（2）を同定した。また (2) の対掌体は BTN に変換されないことから, 図 7の経路を立体化学も含めて確認している.筆 者らは, M.purpurea, M. inyoensis で得られてい る DOS idiotroph についても, 同様にブロック 位置を図6に示すように推定した.このように, DOS 生合成の（1）以降の後半部分は Streptomyces 属, Micromonospora 属, Bacillus 属に共 通であると推定される.グルコースから（1）へ至 る部分の生合成についてはよくわかっていない.

KY 11509 から K 14-1 を精製する過程で，(2) を含むアミノグリコシドがいくつか単離同定され た.いずれも SGM 生合成中間体 (GM-A,$-A$, $\left.-\mathrm{X}_{2}, \mathrm{G}-418\right)$ の 1-deamino-1-hydroxy 誘導体で あった．以上の結果から, SU-2 成分は, DOS生 合成上ステップCがブロックされたため DOI が 蓄積し, DOI がDOS に代って SGM 生合成経路
に直接とり込まれて生成したと 考えられる.アミノサイクリト ール部分を DOS idiotroph を 使った mutational biosynthesis により変換し, 新しい抗生物質 を探す試みは数多いが(6)，この ように DOS idiotroph の代謝 物から新しいアミノサイクリト 一ルを含有する抗生物質を探し た例はそれまでになく，他の生 産菌にも広く応用可能と考えら れた。 そこで, GM 生産菌 $M$. purpurea $\mathrm{SSM}$ 生産菌 $M$. inyoensis, NM 生産菌 S. fradiae で手に入る DOS idiotroph の抗生物質生産の有無を若干検 討したが，残念ながら抗生物質 は検出されなかった。これらの 変異株のブロック位置はステッ プA, BあるいはDで, Cの欠損 変異株はなかった（図 6). 一方, 最近藤原ら ${ }^{(10)}$ は 上述の B. circulans の DOI 蓄積 DOS idiotroph が 1-deamino-1-hydroxy-xylostasin(S-11-A) を 蓄積したことを報告して拉り，M.sagamiensis と 共通した現象として興味深い。

\section{2）転換反応による新規アミノグリコシドの 生成}

生合成研究のために確立した静止菌体を使って の転換反応系を用い, 種及の生合成中間体や抗 生物質を添加すると，生成物の中に新規物質が効 率よく見つかることがわかった．生合成の項で述 べた TPJ-B はその 1 つ例だが，ここではもう 1つの例として 6'-NMV について述べたい。こ の化合物については最初から存在を想定し, 色々 な手法で作り出すことを試みたが，その過程で SGM 生合成の新知見が得られたことは前にも述 べた. 結局, G-52 生産菌 M. zionensis か M. sagamiensis KY 11535 を用いた VDM の転換反 応または M.sagamiensis の DOS idiotroph KY 11525 による JI-20B の転換反応 (この場合は微 
量生成）により目的物質が得られた，転換反応系 では菌体濃度, 基質の種類や濃度, 反応時間を自 由に調節できるし, 生成物の分析や精製も培養ブ ロスに比べて容易なので，発酵では蓄積しない 物質や分析・精製が難しい物質が見つかる効率が 高く，新規物質を見つける 有効な手段といえよ う. 最近, ジェンタミシン生産菌により $\mathrm{KM}$ か ら新規抗生物質 combimicins 生成が報告 ${ }^{(10)} れ れ$ たが，このように転換基質を他の抗生物質に求め るのも面白い方向であろう.

$\mathrm{SGM}$ の生合成, 代謝調節の研究とそれを応用 した菌株改良, 新規アミノグリコシド抗生物質の 検索について述べてきた。ここに示した例でもわ かるように，一般的に二次代謝の酵素は一次代謝 のように基質特異性が高くなく，1系列中の 1 つ の酵素に対する基質とその生産物が別の酵素の基 質となりらる. したがって，いわゆる“metabolic network”といわれる網目状の経路が考元られ， 培養条件や菌株の違いによって主たる経路が決ま ると考えられている.これまで述べたいくつかの 観点からの研究結果を総合してみると, SGM 生 産菌として発見された M. sagamiensis が，実は 図 7 に示すような, SGM を含む関連アミノグリ コシドの複雑多枝に分かれた生合成経路を有して いたことがわかる、親株では図 3 に示した SGM 生合成が 主経路であるが，変異株では，経路上 のあるステップがブロックあるいは強化された 結果，ある場合には SGM 力価向上へつながり， ある場合には通常ではほとんど機能していない副 経路が拡大され，新規物質が蓄積してくると考え られる。このような特性に抗生物質の生合成や菌 株改良の研究の難しさがあり，同時に面白さがあ るのではないだろらか. SGM 生合成については, 輪郭をようやく捕えられたといら段階であり，本 文中に述べたように残された問題点は多い. 生合 成の調節についても，他の二次代謝産物同様，い くつかの断片がわかってはきたが，まだ本質的な ところに至れないのが現状であろう．抗生物質の 合理的な研究方向を可能にするのは，こういった
問題を一つ一つ解明していく努力の蓄積ではない かと考える. 微生物遺伝学を含めて, 分子生物学 の著しい進歩に対比して, 抗生物質生合成の遺层 生化学的面の進歩はな掯いが, 遺伝的手法や, 抗生物質生産に関与するプラスミドの操作も含め た遺伝子工学の手法によっても，抗生物質生産菌 の改良や，新抗生物質の創成が期待される現在， 個々の抗生物質についての生合成および遺伝の基 礎的研究の蓄積がより要求されるであろう.

本研究は, 筆者を含めた共同研究グループの研究成果の一部 をまとめたるのであり，終始御指導いただいた中山清協和醗酵 工業(株)理事をはじめ, 共同研究者 (山口健, 小田倉義博, 屉 藤菁莪, 高沢命匡, 本多春雄, 北村重人, 白幡公勝, 飯田孝 男）各位に深く感謝いたします。

\section{文 献}

1) K. L. Rinehart Jr. \& R. M. Stroshane : J. Antibiot., 29 319 (1976).

2) R.T.Testa \& B.C. Tilley : Jpn. J. Antibiot., 32, S47 (1979).

3) B. K.Lee, J. V. Bailey, R. G. Condon, J.A. Marquez, G. H. Wagman \& M. J. Weinstein : Antimicrob. Agents Chemother, 12, 335 (1977).

4) R. Okachi, S. Takasawa, T. Sato, S. Sato, M.Yamamoto, I. Kawamoto \& T. Nara: J. Antibiot., 30, 541(1977).

5) H. Grisbach : Adv. Carbohydr. Chem. Biochem., 35, 81 (1978),

6) S. J. Daum \& J. R. Lemke : Ann. Rev. Microbiol., 33, 241 (1979).

7) J. B. Walker : Dev. Ind. Microbiol., 21, 105 (1980).

8) T.Furumai, K. Takeda, A. Kınumaki, Y. Ito \& T. Okuda : J. Antibiot., 32, 891 (1979).

9）藤原民雄: 化学々生物, 19, 229 (1981).

10) Y. Oka, H. Ishida, M. Morioka, Y. Numasaki, Y. Yamafuji \& T. Osono: J. Antibiot., 34, 777 (1981).

11) T. Deguchi, S. Okumura, A. Ishii \& M. Tanaka $: J$. Antibiot., 30, 993 (1977).

上記の文献は 1)，2，5，6)，7)，9）など総説を選んで揭 げたが，他に参考になると思われる総説る以下に記しておく.

○S. W. Queener, D. K. Sebek \& C. Vézina: Ann. Rev. Microbiol., 32, 593 (1978).

- K. L. Rinehart Jr.: Jpn.J. Antibiot., 32, S-32 (1979).

- J.F.Martin \& A.L. Demain : Microbiol. Reo., 44, 230 (1980).

。能美良作 : 醇醉工学, 56, 479 (1978).

-中山 清: Amino Acid Nucleic Acid, 36, 1 (1978).

。奈良 高: 発醉と工業, 37, 735 (1979).

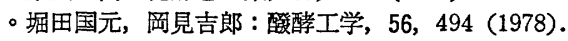

